\title{
DRAMATURGIA RADIOWA WEDŁUG JERZEGO SZANIAWSKIEGO
}

W okresie dwudziestolecia międzywojennego, dokładnie w 1917 roku, Jerzy Szaniawski zyskał sławę jako dramatopisarz. Wówczas wystawiona zostało jego pierwsza komedia zatytułowana Murzyn. Premiera miała miejsce w Teatrze Polskim w Warszawie. Zdaniem Krystyny Nastulanki, w dramatach Szaniawskiego dominuje uniwersalizm, wydarzenia przedstawiane w utworach mogłyby mieć miejsce w każdym mieście i w każdym czasie. Nastulanka tezę tę argumentuje za pomocą opisu Ptaka: „Sprawy, które dzieją się w miasteczkach Szaniawskiego, przeżycia, jakie sa udziałem jego bohaterów, mogłyby się zdarzyć w każdym zamkniętym środowisku, wśród ludzi pewnie zakotwiczonych w życiu, wygodnie rozpartych $w$ swoich fotelach $i$ pilnie strzegacych ustalonego przez siebie ładu i nienaruszalności hierarchii". ${ }^{1}$

Szaniawski po premierze Murzyna zaczął tworzyć nowe dramaty, wydawane cytując za Hutnikiewiczem - w następującej kolejności: Papierowy kochanek (1920), Ewa (1921), Lekkoduch (1923), Adwokat i róże (1929), Ptak (1923), Żeglarz (1925), Fortepian (1932), Most (1933), Zegarek (1935), W lesie (1937), Stużbista (1937), Srebrne lichtarze (1938), Dziewczyna z lasu (1939), Dwa teatry (1946), Kowal, pieniadze i gwiazdy (1948) oraz Chłopiec latajacy (1949). ${ }^{2}$ Za najbardziej radiowe, pisane w wyniku współpracy z radiem, uznane zostały dramaty z lat 1935 - 1938 . Jerzy Szaniawski tworzył swoje dzieła nie tylko w okresie dwudziestolecia międzywojennego, ale także dwudziestopięciolecia powojennego. Jego dramaty z łatwością mogą zostać przekształcone na utwór nowelistyczny czy też przypowieść. Krystyna Nastulanka wymienia najważniejsze cechy twórczości Szaniawskiego, które opierają się na zestawieniu dwóch przeciwstawnych biegunów jego twórczości: ,pozornie sceptyczny - jakże dobrze rozumie i pokazuje Szaniawski ludzkie namiętności. Niezmiernie zwięzły - ileż potrafi wyrazić. Świetnie sięgający do wspomnień -jakże mocno umie żyć teraźniejszościa, a także przyszłościa". 3 Szaniawski nawiązał

\footnotetext{
* Mgr Urszula Motyka -Katedra Dramatu i Teatru KUL, e-mail urszulamotyka@wp.pl.

1 K. Nastulanka: Jerzy Szaniawski. Warszawa 1973, s. 45-46.

2 A. Hutnikiewicz: Wstęp (w:) J. Szaniawski, Wybór dramatów, s. VIII-X.

${ }^{3}$ K. Nastulanka: Jerzy Szaniawski. Warszawa, 1973.
} 
współpracę z radiem w 1935 roku. Wówczas miała miejsce prapremiera Zegarka. Obok dramatów Szaniawski pisywał również monografie - między innymi Juliusza Osterwy w 1958 roku, którą stworzył wraz z J. Hennelową, a także opowiadania oraz niewielkie utwory nawiązujące poprzez swą formę do nowelistyki: „Debiutowat w r. 1912 króciutkimi utworami nowelistycznymi i humorystycznymi na łamach «Kuriera Warszawskiego» i satyrystycznego tygodnika «Sowizdrzał», podpisujac je kryptonimami J. Sz., Jotes, Żak. Zebrat je później w r. 1928 w tomie opowiadań pt. Lgarze pod Złota Kotwica. Z tych inklinacji satyrycznych $i$ humorystycznych, zreszta bardzo w swym dowcipie łagodnych, wyrosty w latach późniejszych świetne Opowiadania profesora Tutki". ${ }^{4}$

Z natury był człowiekiem pozostającym w cieniu swych dramatów, unikał relacji z towarzystwem literackim Warszawy. Kontakty utrzymywał jedynie z „Redutą”, co związane było z zamiłowaniem do teatru. Jego utwory transmitowano, między innymi, w radiorozgłośni w Szwecji (Adwokat i róże), Belgii (Ptak) oraz Sztokholmie. Audycja sztokholmska miała miejsce w grudniu 1931 roku i był nią Żeglarz, jednakże z pewnymi modyfikacjami. Musiano zamienić nazwisko kapitana z Nuta na Łada, ze względu na szwedzkie tłumaczenie oryginalnego nazwiska, która oznacza w tymże języku stodołę. ${ }^{5}$

Szaniawski w dzieciństwie dostawał od swojej matki w prezencie liczne lalki. Jedna z nich dała początek pytaniom jakie w swojej twórczości autor często sam sobie zadawał. Jego twórczość opierała się na próbie ukazania świata wewnętrznego bohaterów. Kolińska cytuje fragment wypowiedzi Szaniawskiego na temat tego wspomnienia: „Pociątem tę lalkę (...) żeby zobaczyć, co jest w niej, w środku... Cała późniejsza praca mojego życia była takim poszukiwaniem, takim badaniem wnętrza człowieka. I odkrywaniem, że w tym wnętrzu, obok czy oprócz pakut, kryja się także rzeczy inne. Często wartościowe i piękne". ${ }^{6}$

Modelowym tekstem dla słuchowiska radiowego jest Zegarek, który - jak podaje Aneta Wojciszyn-Wasil - okazał się utworem umiarkowanym, jeśli chodzi o podanie słowa przeznaczonego do wypowiedzenia na antenie, oraz spójnym treściowo i kompozycyjnie: „dialog z Zegarka Szaniawskiego nosi wszelkie znamiona dobrze skonstruowanego stowa radiowego. Krótkie, precyzyjne zdania, z których każde wnosi znaczący ladunek informacyjny. Kolejne dane niezbędne do szczegótowej konstrukcji postaci czy sytuacji sa podawane naturalnie, jakby przy okazji, mimochodem"?

O tymże dramacie Szaniawskiego pisali między innymi Tymon Terlecki i Karol Irzykowski, którzy byli zdania, że sztuka ta może zachwycać kameralnością oraz precyzją podania słowa. ${ }^{8}$

\footnotetext{
${ }^{4}$ A. Hutnikiewicz: Wstęp (w:) Jerzy Szaniawski: Wybór dramatów, s. VIII.

${ }^{5}$ M.J. Kwiatkowski: Polskie Radio 1925-1939 , „Pamiętnik Teatralny” 1973, z.3-4, s. 393.

${ }^{6}$ K. Kolińska: Szaniawski. Zawsze tajemniczy. Warszawa 2009, s. 19.

7 A. Wójciszyn-Wasil: Sztuka radiowa w Polsce i jej krytyka do 1939 roku, Lublin 2012, s. 125.

8 Tamże, s. 167.
} 
Dramat radiowy powinien być pisany na wzór noweli i posiadać jej główną cechę jaką jest wyróżnienie jednego najistotniejszego ogniwa spajającego kompozycję tekstu. Wspominał o tym Terlecki, który odnalazł cechy wspólne między Zegarkiem a Kamizelka Bolesława Prusa: „Terleckiemu Zegarek nasuwał ewidentne skojarzenia z Kamizelka Prusa: „Pospolity przedmiot jest sprawdzianem postawy człowieka wobec człowieka”. Wyjątkowo radiofoniczna metoda konstrukcji radiowego obrazu jest zatem detal, który rozrasta się w bogata znaczeniową całość"’9.

Tymon Terlecki w cytowanej przez Anetę Wójciszyn-Wasil publikacji wskazuje na walory tekstu dramatu Szaniawskiego, w momencie wypowiadania go przez aktora na antenie: „Ściszone, intymne słowo Szaniawskiego, powierzone w zawstydzeniu, w ostatecznym przymusie i głębokim poczuciu ufności - może zabrzmieć $w$ membranie mikrofonu petnodźwięcznością spowiedzi”. ${ }^{10}$

Twórczość Szaniawskiego bogata jest w elementy słuchowiskowe, które warunkują możliwość ich realizacji na antenie radia. Szaniawski okazał się pisarzem wyjątkowym. W jego wrażliwości artystycznej pojawiały się elementy, które predestynowały go do tworzenia w nowej rzeczywistości radiowej. Dopiero później sztuka radiowa przejęła te elementy. Szaniawski był gotowy współpracować z tą nową rzeczywistością. Właśnie przez tę wrażliwość radiowcy zwrócili uwagę na twórczość omawianego pisarza, który stał się dla nich postacią bardzo ważną. W niniejszym artykule odniosę się do następujących dramatów: Adwokat i róże, Żeglarz, Ptak, Służbista oraz Zegarek, które analizować będę pod względem wykorzystania w nich elementów akustycznych, dialogów, relacji, retrospekcji, niedopowiedzeń oraz niedomówień.

\section{ELEMENTY AKUSTYCZNE}

Akcja dramatu Adwokat i róże rozpoczyna się w momencie, gdy dwóch chłopców biegnie ulicą, wykrzykując tytuły sprzedawanych gazet, o czym informuje, poprzez swoją wypowiedź, Jakub, który kupuje gazety od jednego z chłopców. Bardzo mocno wyeksponowane zostały elementy akustyczne, którymi są okrzyki dostarczycieli gazet, a które zaznaczone są zarówno w didaskaliach jak i w wypowiedzi Jakuba. Pojawienie się Siostrzenicy Mecenasa, Janeczki, zasygnalizowane zostało w didaskaliach kolejnym elementem dźwiękowym - dzwonkiem przy furtce. Ów dzwonek jest stałym sygnałem w momencie przybywania postaci. Akt I kończy pojawienie się Złodzieja wykrzykującego, że zabił człowieka. Jego pojawieniu się towarzyszą także elementy

9 Tamże, s. 167 .

10 T. Terlecki: Szaniawski przed mikrofonem (w:) A. Wójciszyn-Wasil: Sztuka radiowa w Polsce i jej krytyka do 1939 roku. Lublin 2012, s. 168. 
dźwiękowe, zaznaczone w didaskaliach - „trzask łamanego krzewu"l1. Akustyka w postaci okrzyków sprzedawców gazet widoczna jest również w tekście pobocznym wprowadzającym w akt III. Do dramatu Szaniawski wprowadza także ciszę, sygnalizowaną $\mathrm{w}$ didaskaliach milczeniem bohaterów. Zastosowanie tychże elementów powoduje, że odbiorca dokładniej może wyobrazić sobie prezentowane wydarzenia.

W Żeglarzu natomiast podstawowym elementem akustycznym jest cisza, zarówno w postaci pauz $\mathrm{w}$ trakcie wypowiedzi jednego bohatera, jak i wypełnionego milczeniem czasu pomiędzy kwestiami różnych bohaterów. Cisza zasygnalizowana jest $\mathrm{w}$ didaskaliach poprzez zaznaczenie milczenia postaci, bądź też $\mathrm{w}$ samym tekście poprzez wielokropek. Przykładem niech będzie wypowiedź Med: „Tak.. mogę zrozumieć, że dla niego stara mumia więcej warta niż młoda... narzeczona... Ale zrozumieć to przez póttora roku, to trochę... za dtugo..." ${ }^{2}$ Obok ciszy w didaskaliach zaakcentowane zostały również protezy dźwiękowe, jak - między innymi - westchnienie. Natomiast w wypowiedziach niektórych bohaterów Szaniawski zawarł wyrazy dźwiękonaśladowcze, wzmacniające akustykę tegoż dramatu. Autor zaznaczył, także w didaskaliach, w momencie powrotu Jana, słyszalne w oddali głosy trzech postaci, przy czym zmienia się natężenie tychże głosów, co sprawia wrażenie zbliżania się postaci ku obecnym na scenie osobom. Kolejnym elementem dźwiękowym zasygnalizowanym w didaskaliach i w wypowiedzi Med, jest odgłos zbliżających się kroków. Nie zostało to powiedziane wprost:

$$
\begin{aligned}
& \text { „MED } \\
& \text { - Nie... Czekam... } \\
& \text { (Nadstuchuje) } \\
& \text { - Ktoś idzie do nas". }{ }^{13}
\end{aligned}
$$

Dzwonek do drzwi, to następny zaznaczony w didaskaliach elementy dźwiękowy, oznaczający przybycie kolejnych bohaterów do domu Rzeźbiarza. Obok dzwonka ważnym elementem - także ukazanym w tekście pobocznym - są odgłosy orkiestry (flety, trąby, bębny) oraz okrzyki tłumu w czasie uroczystości odsłonięcia pomnika. $\mathrm{O}$ bijących dzwonach czytelnik dowiaduje się z rozmowy Doktorowej, Izy oraz Felci.

Szaniawski, identycznie jak w wyżej zanalizowanych dramatach, tak i w Ptaku operuje ciszą. Widoczna jest w dialogach bohaterów, a zaznaczona została przede wszystkim w didaskaliach poprzez zwrócenie uwagi na milczenie postaci. Dodatkowo w wypowiedziach wyeksponowano, poprzez zastosowanie wielokropka, pauzy. W didaskaliach uwydatniono ton oraz barwę głosu bohaterów - mówią oni cicho, „ze zdziwieniem, z zachwytem, marząco, jak w modlitwie, w zamyśleniu, jak przez sen, chciwie, grożąc". ${ }^{14}$ Wyraźnymi elementami dźwiękowymi są: odgłos

\footnotetext{
${ }_{11}$ J. Szaniawski: Adwokat i róże (w:) tegoż: Wybór dramatów. Wrocław 1988, s. 218.

12 J. Szaniawski: Żeglarz (w:) tegoż: Wybór dramatów. Wrocław 1988, s. 97.

13 Tamże, s. 98.

14 J. Szaniawski: Ptak, s. 33-36.
} 
dzwonka, przypominającego chiński gong, zamieszczony u drzwi mieszkania Studenta, bijący na wieży zegar, muzyka na ulicach miasta oraz melodia hejnału, o których mowa jest $\mathrm{w}$ didaskaliach.

W przypadku zaś Stużbisty, w przeciwieństwie do poprzednich utworów, elementy dźwiękowe nie są wyeksponowane. Wyjątek stanowi odgłos kroków, odsuwanego krzesła oraz odjeżdżającej furki. Dodatkowym elementem dźwiękowym jest zanucona przez Hanię piosenka. W dramacie tym, Szaniawski zwraca przede wszystkim uwagę na sposób wypowiadania treści, wobec czego w didaskaliach zaznaczony jest sposób intonacji, zmiana wysokości tonu oraz emocje. Bohaterowie mówią z zainteresowaniem, żywiej, na wpół do siebie czy też wesoło, śmiało i swobodnie. Wesołość bohaterów bywa niekiedy sztuczna. Zaakcentowane są także pauzy, zaznaczone zarówno w didaskaliach, jak i wplatane w dialogi bohaterów, przykładowo w wypowiedziach Pułkownika: „Prosić pana Zadorę. (po chwili) Witam.” czy ,Tak. Czterdzieści pięć lat - to na ogót poważna przeszkoda. (chwila namystu) Czy jesteś żonaty?". 15

Zegarek natomiast zawiera wiele różnorodnych sygnałów dźwiękowych. Akcja tegoż utworu rozpoczyna się odgłosem dzwonka telefonicznego. Wyraźnie zaznaczone są także zmiany natężenia i wysokości tonu w wypowiadanych przez bohaterów kwestiach, podkreślane we wplatanych w wypowiedzi wskazówkach reżyserskich, jak chociażby w kwestii Szefa:

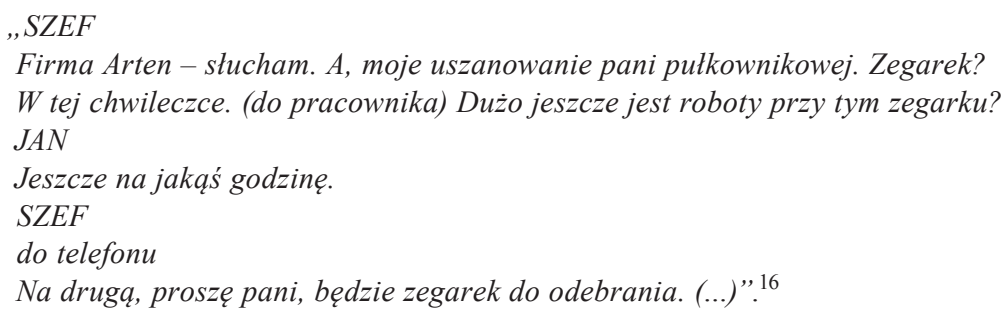

Dodatkowo zmiana tonu, sygnalizująca upodobnienie wypowiedzi do kwestii wygłoszonej przez inną postać, została zaznaczona - podobnie jak w Stużbiście poprzez ujęcie powtarzanego zwrotu w klamrę:

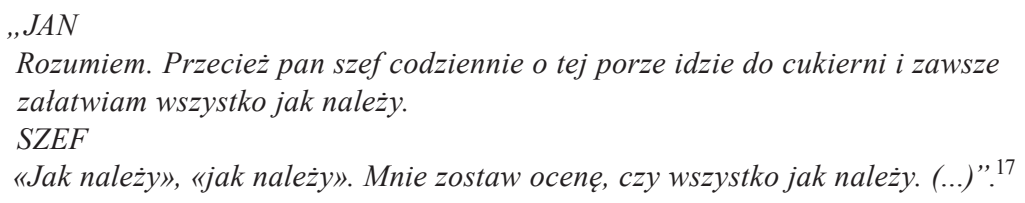

15 J. Szaniawski: Stużbista (w:) tegoż: Dziewczyna z lasu; Dwa teatry; Kowal, pieniadze i gwiazdy; Stużbista; Zegarek. Kraków 1958, s. 291-292.

16 J. Szaniawski: Zegarek, s. 345.

17 Tamże, s. 322. 
Pauzy oraz milczenie bohaterów podkreślone zostały w tekście poprzez użycie wielokropka oraz wplecione w wypowiedzi bohaterów uwagi reżyserskie, typu: po chwili, krótkie milczenie, chwilowa pauza. Wyraźnym sygnałem dźwiękowym w utworze jest powtarzający się odgłos bicia zegarów, które „biją rozmaicie”18 oraz turkot przejeżdżających ulicą wozów do przewożenia węgla - odgłos ten wpływa na dalszy przebieg akcji. Bohaterowie mówią bądź to zrzędliwie, niemal z przerażeniem, bądź ze zdumieniem, godnością czy też z irytacją lub gorączkowo, $\mathrm{z}$ naciskiem - zmiany te ukazane zostały w didaskaliach.

\section{DIALOGI}

W utworze Adwokat i róże, główny bohater - Mecenas - pojawia się na scenie, gdy Jakub czyta zakupioną przed chwilą gazetę. Nawiązuje się rozmowa, przeważnie oparta na krótkich, lapidarnych pytaniach i odpowiedziach, dotycząca treści gazety, przede wszystkim zaś Jakub zwraca uwagę na wyrok -8 lat pozbawienia wolności - dla tych „co napadli omnibus pod Wadowicami”" ${ }^{\prime}$. Następnie dialog płynnie przechodzi na temat doskonałej pracy, jaką przed emeryturą wykonywał Mecenas. Jakub sugeruje, że jego rozmówca, wówczas gdy jeszcze był obrońcą, potrafił wygłaszać mowy uniewinniające każdego skazanego, dlatego też twierdzi, że gdyby to Mecenas ich bronił, uniknęli by więzienia.

Siostrzenica przynosi Mecenasowi informację, jaką znalazła w jednej z gazet. Informacja ta dotyczy wygranego przez Adwokata Wilchera, pokazu róż, który miał miejsce w Berlinie. W związku z wygraną do Mecenasa przychodzi także Przyjaciel, aby mu pogratulować. O postawie i emocjach Przyjaciela dowiadujemy się z rozmowy, jaka zachodzi między nim a Siostrzenicą, która zauważa: ,,Jest pan, jak zawsze, obojętny i smutny"20. Pomiędzy Przyjacielem, Mecenasem i Siostrzenicą nawiązuje się dialog, poświęcony pracy i starości. $\mathrm{Z}$ rozmowy trójki bohaterów wynika, że Mecenas codziennie o określonej godzinie uczęszcza na zebraniach biologów. Janeczka jest zdania, że wygraną Mecenasa należy uczcić wystawną kolacją, na którą zaproszeni zostaną wszyscy mieszkańcy i przyjaciele domu. W tym momencie prezentowane są także wyobrażania Siostrzenicy, która dokładnie opisuje jak widziałaby przyjęcie, co ułatwia odbiorcy zarysowanie przestrzeni.

U Mecenasa pojawia się Łukasz. Mecenas początkowo jest przekonany, że młodzieńcowi chodzi o pobieranie nauk adwokackich. Jednakże niespodziewany gość domu Wilcherów pragnie kształcić się na hodowcę róż pod okiem specjalisty. Za-

\footnotetext{
18 Tamże, s. 322.

19 J. Szaniawski: Adwokat i róże, s. 194.

20 Tamże, s. 201.
} 
znacza przy tym, że kierują nim inne aspekty, nie tylko wysokie zarobki. Kolejnym gościem Adwokata jest Dama. Jej zdaniem tylko Mecenas może obronić jej syna, domniemanego Złodzieja róż. Przed podjęciem decyzji Adwokat opuszcza Damę, ponieważ ma spotkanie u rejenta. W tym miejscu autor wzmacnia napięcie u odbiorcy. Na scenie pojawia się Dorota. Między nią a ,piękną Franią” nawiązuje się krótka rozmowa. W wypowiedziach Doroty można dostrzec zdenerwowanie zaistniała sytuacją, można odnieść wrażenie, że stara się coś ukryć. Świadczą o tym także gesty opisane w didaskaliach. Adwokat po powrocie oznajmia Damie, że jednak nie może podjąć się obrony, ponieważ w Sądzie będzie musiał wystąpić jako świadek, ale proponuje jako obrońcę swojego ucznia Marka. Po odejściu Damy, do ogrodu wchodzi Marek. Mecenas mówi mu o swoich planach, po czym ponownie udaje się do rejenta. Na scenie pojawia się Agent, który tłumaczy Markowi, jakie były prawdziwe intencje Złodzieja. Jest zdania, że nie chciał on ukraść róż, ale jego celem była żona Mecenasa - Dorota, która najprawdopodobniej ma z nim romans. Marek nerwowo reaguje na opinie Agenta i nakazuje mu milczenie. Agent, przestraszony nagłym wybuchem Marka, ucieka z ogrodu, na scenie natomiast pojawia się Dorota, która wydaje się być zaniepokojoną dziwnym zachowaniem Marka. W jej wypowiedziach zaznaczony zostaje ton głosu jej rozmówcy. Niespotykane dotychczas zachowanie Marka zauważa także Łukasz. Między mężczyznami nawiązuje się rozmowa dotycząca pracy i ich wspólnego nauczyciela.

W dialogach bohaterów Żeglarza widoczne są powtórzenia, co zbliża formę ich wypowiedzi do mowy potocznej. Przykładem powtórzenia może być wymiana zdań między Rzeźbiarzem a Janem:

$$
\begin{aligned}
& \text { „RZEŹBIARZ } \\
& \text { - Model pomnika... } \\
& \text { JAN } \\
& \text { - Model-pomnika? "21 }
\end{aligned}
$$

Dodatkowym zbliżeniem do mowy potocznej są czynniki paralingwistyczne typu „Ba...ba...”22 w wypowiedzi Rektora oraz zwroty, między innymi, „tego ten”, jakimi posługuje się Przewodniczący. Takie zwroty powodują również, że wypowiedź staje się niezrozumiała, czytelnik musi sam doprecyzować jaka myśl została zawarta w zdaniu. Ma to miejsce w wypowiedzi Przewodniczącego dotyczącej używania siły wobec kobiet: „Ale ja twierdzę, że mężczyzna powinien kobiete tego... coś... bo w przeciwnym razie... ona nas... tego ten..."23. Podobny chwyt niedopowiedzenia oraz zbliżenia do mowy potocznej został zawarty w rozmowie Przewodniczącego ze Szmidtem:

\footnotetext{
${ }^{21}$ J. Szaniawski: Żeglarz, s. 104.

22 Tamże, s. 100.

${ }^{23}$ Tamże, s. 118.
} 


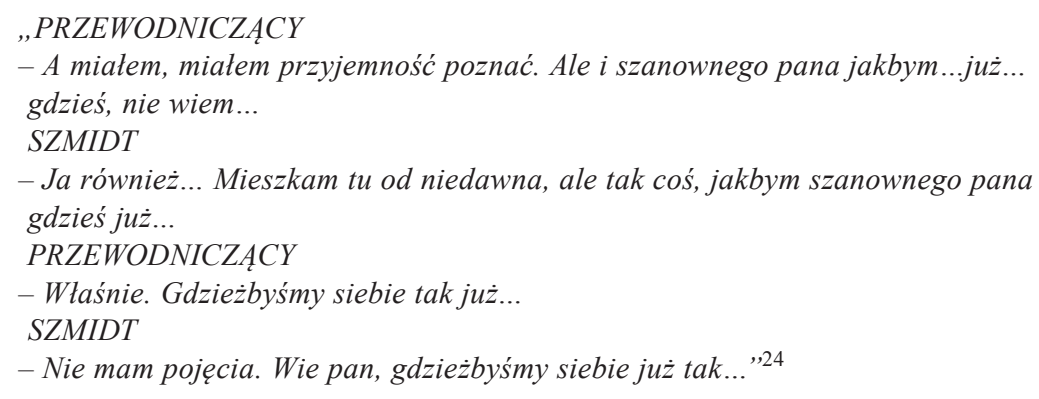

Zawarty w niektórych wypowiedziach bohaterów czasownik „słuchać” sprawia, że dramat ten uzyskuje kompozycję otwartą. Odbiorca jest stale obecny, jedynie przysłuchuje się wymianie zdań, o czym świadczy otwarta kompozycja dzieła.

Dialog w dramacie Ptak pełni w dużym stopniu funkcję informacyjną. O tym, że na sali obrad pojawiają się kolejni radcy odbiorca dowiaduje się z samego dialogu bohaterów, poprzez powtarzający się zwrot „witam”. O pojawieniu się Michałka czytelnik także zostaje poinformowany: „Jest Michałko”25. Z konwersacji prowadzonych przez radnych czytelnik dowiaduje się jakie czynności wykonują w danej chwili. Przykładowo: Wynalazca dokładnie opisuje wykonywane przez siebie czynności w czasie prezentacji swojego Pajaca.

Nastrój oraz wygląd i ubiór bohaterów także zostały przedstawione wprost przez innych uczestników dyskusji, niekiedy jedynie w didaskaliach. W dialogach występujących w komedii postaci widoczne jest zbliżenie stylu ich wypowiedzi do formy mowy potocznej („Coo?”26), dodatkowo - podobnie jak w Żeglarzu - pojawiają się czynniki paralingwistyczne, chociażby w odpowiedziach Burmistrza w rozmowie z Radcą Anzelmem:

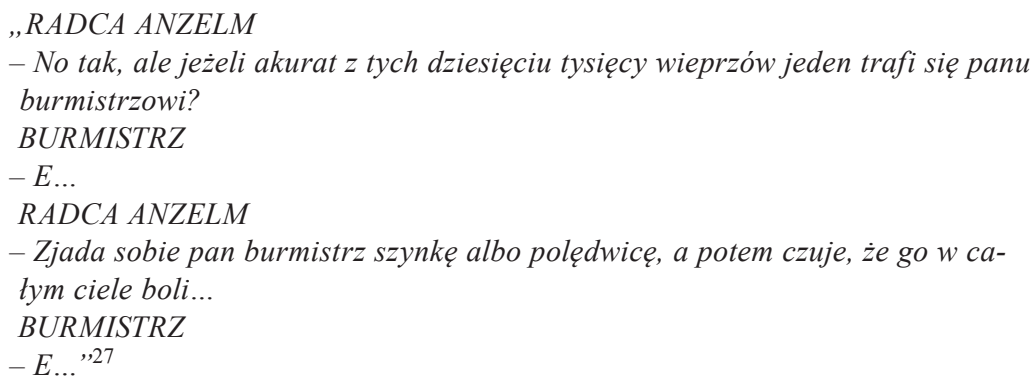

Dodatkowo pojawiają się wyliczenia, nadające rozmowie naturalny przebieg. Zaś zamyślenie bohaterów zostało wyeksponowane poprzez powtarzające się w kilku

\footnotetext{
${ }^{24}$ Tamże, s. 148.

25 J. Szaniawski: Ptak, s. 21.

26 Tamże, s. 20.

27 Tamże, s. 9.
} 


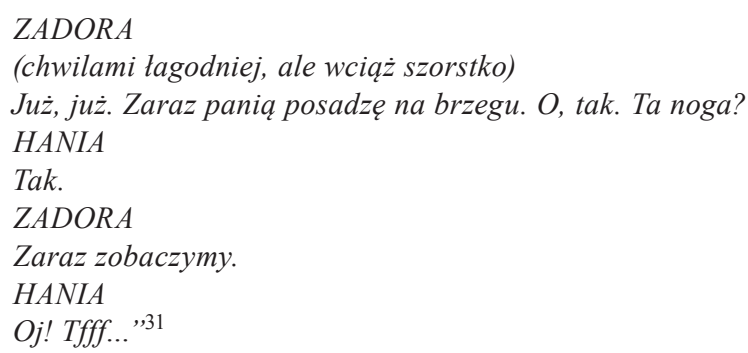

Pytania i instrukcje postępowania kierowane do Hani, wpływają na wyobraźnię odbiorcy, który może odnosić wrażenie, że dokładnie widzi reakcje dziewczyny: „Co pani mówi? Czy pani zasłabła? Proszę tu do brzegu! No, niech się pani stara przybić do brzegu. Przecież blisko. (po chwili) O tak. No, już. Co pani jest?’’32.

Zegarek - już z pierwszej wypowiedzi Szefa, odbiorca dowiaduje się, że akcja rozgrywa się w siedzibie firmy Arten. Kwestie bohaterów budowane są tak, aby wyraźnie były zaznaczone przejścia pomiędzy adresatami poszczególnych zwrotów. W dialogach zaprezentowano zachowania postaci, uzupełnione dodatkowo w didaskaliach. Pojawianie się w sklepie Mecenasa, zostało zaznaczone w wypowiedzi Jana, podobnie o powrocie Szefa oraz o wizycie Jana u Pani czytelnik zostaje poinformowany w prost $\mathrm{w}$ dialogach pojawiających się $\mathrm{w}$ danym momencie osób. Z rozmowy bohaterów czytelnik może także zbudować obraz przestrzeni dramatycznej. Pojawia się również stylizacja na formę mówioną, język potoczny, widoczne są momenty zastanawiania się nad dalszą częścią wypowiedzi, zwłaszcza w odpowiedziach Jana, gdy jest przesłuchiwany przez Szefa. W jego odpowiedziach występują także powtórzenia, niespójna składnia zdania oraz widoczne jest zdenerwowanie bohatera wyrażone w zająkiwaniu się: , Ja, ja... nie... to jest... tu na pewno byt tylko pan mecenas” czy też „Dziu... Dziunia..." ${ }^{33}$. Wypowiedzi bohaterów zazwyczaj są rozbudowane, nie przybierają formy krótkich, lapidarnych zdań.

\section{RELACJA}

Relacja w Adwokacie i różach pojawia się w Akcie III, który to rozpoczyna się gdy Siostrzenica i Dorota oczekują na wiadomości z sali sądowej, na której odbywa się rozprawa Złodzieja. Na dwór Mecenasa przychodzą Jakub, Łukasz oraz Przyjaciel. Złodziej za sprawą mowy obronnej Marka zostaje uniewinniony,

\footnotetext{
${ }_{31}$ Tamże, s. 301-302.

32 Tamże, s. 301.

33 J. Szaniawski: Zegarek, s. 325-328.
} 
o czym informuje przybyły z Sądu Mecenas. Pojawiający się goście relacjonują wydarzenia z Sądu, dzięki czemu odbiorca może być w dwóch miejscach jednocześnie (zastosowanie montażu równoległego). Relacje poszczególnych postaci dramatu wprowadzają do utworu element narratywny. Do przedstawienia wydarzeń z przeszłości bohaterowie używają czasu teraźniejszego. Pojawiają się także sformułowania: „Mówia, że oskarżony nie powinien po tej obronie dostać więcej niż trzy lata” czy „Oczekuja wyroku”34.

Relacją rozpoczyna się Akt III Żeglarza. Felcia i Iza opisują w swojej rozmowie wydarzenia jakie mają miejsce na placu, który obserwują z okna restauracji „Pod Witrażami”. Relacja przedstawiona jest w czasie teraźniejszym. Z dialogu dziewcząt czytelnik dowiaduje się, że „,...), na dachy wchodza chtopaki",35, policjanci chodzą w białych rękawiczkach, dodatkowo na plac wchodzą sportowcy, służby mundurowe, strzelcy oraz duchowieństwo. Na placu gdzie ma zostać odsłonięty pomnik kapitana Nuta pojawia się coraz więcej osób. Do relacji dziewcząt włącza się także Przewodniczący obserwujący niebo, zastanawiający się, czy pogoda się nie popsuje. Dołącza do nich również Kapelmistrz, mówiąc, że orkiestra nie chce grać. Wcześniejsza rozmowa Felci, Izy i Doktorowej dotyczyła przygotowań do uroczystości, w miarę rozwoju akcji dialog płynnie przechodzi w relację z samej ceremonii. Kobiety wspominają o dzieciach ubranych na biało oraz parafrazują wypowiedź Rektora. Zabieg wprowadzenia relacji z miejsca uroczystości, przy równoczesnym toku akcji w restauracji, stwarza w czytelniku wrażenie, że uczestniczy zarówno w wydarzeniach rozgrywających się w „Pod Witrażami” jak i na placu przed restauracją.

W Ptaku elementy relacji zastosował Szaniawski w dialogu Radcy Anzelma, Burmistrza i Radcy Sebastiana. Ostatni z bohaterów przedstawiał pozostałym zebranym przypadek swojego znajomego, który zachorowawszy poszedł do lekarza, którego jednak nie zastał, ponieważ udał się on zagrać z dziećmi swoich znajomych w loteryjkę. Następnie ów znajomy udał się do felczera - jego również nie było. Taka sama sytuacja miała miejsce w aptece - aptekarz w tym czasie był na zebraniu, a jego żona, malarka, była zbyt zajęta odcieniem ścian, aby pomóc choremu. W wyniku tejże bezowocnej wędrówki, jak podaje Radca Sebastian, jego znajomemu pozostało wyzdrowieć. Student zaś relacjonuje lot swojego złotego ptaka.

Natomiast w Stużbiście Szaniawski wprowadza element relacji w momencie pojawienia się w dramacie Hani. Zarówno Zadora jak i kobieta relacjonują wydarzenia związane z jej wyprawą kajakiem, jednakże relacja ta prowadzona jest z dwóch punktów widzenia - z perspektywy Hani, oraz z perspektywy dozorcy. Zadora zwraca jedynie uwagę na omdlenie kobiety w kajaku, ona zaś przedstawia przebieg wydarzeń od momentu próby wyjścia z łódki do chwili gdy zemdlała.

\footnotetext{
34 J. Szaniawski: Adwokat i róże, s. 257-258.

35 J. Szaniawski: Żeglarz, s. 156.
} 


\section{RETROSPEKCJA}

Zabieg retrospekcji w twórczości Szaniawskiego można omówić na podstawie trzech z pięciu prezentowanych dramatów. W Adwokacie i różach tenże zabieg artystyczny został wykorzystany już w pierwszej rozmowie Jakuba z Mecenasem. Po krótkiej wymianie zdań dotyczącej dawnego zawodu Mecenasa, Jakub wspomina o „pięknej Frani”, dawnej klientce Adwokata. Zabieg ten pozwala na przedstawienie odbiorcy dawnych czasów ważnych dla bohaterów i istotnych dla dalszego przebiegu akcji. W Stużbiście zjawisko retrospekcji pozwala na ukazanie wspólnych wspomnień Zadory i Pułkownika ze studenckich czasów. Wrażenie sentymentalnego powrotu do zamierzchłych czasów potęguje powtarzający się wielokrotnie zwrot „pamiętam”. Bohaterowie, rozmawiając o przeszłości, odnoszą się do teraźniejszości, do sytuacji i zachowań, o których Zadora musi zapomnieć podejmując służbę starszego dozorcy. Ze wspomnień postaci odbiorca dowiaduje się, że w przeszłości Zadora jako student był „zawsze taktowny, dyskretny, opanowany" ${ }^{\prime 36}$, nie stronił od alkoholu, miewał różne miłostki, grał na fortepianie, nigdy natomiast nie grywał w karty. Element retrospekcji zastosowany został także w wypowiedzi Hani skierowanej do Zadory, w której przywołuje wydarzenia dnia poprzedniego, gdy to pierwszy raz dłużej z nią rozmawiał, pretekstem zaś dla tej rozmowy było stado dzikich gęsi. Wydarzenia te przeplatane zostały wspomnieniami Hani z dzieciństwa, gdy mówiono na nią, że jest jak dzika gęś.

Retrospekcją w Zegarku Szaniawski posłużył się w celu wyjaśnienia spraw z przeszłości. Zjawisko to pojawia się w rozmowie Jana z Panią, czyli siostrą żony pana Artena. Zabieg ten początkowo przybiera formę wspomnień Jana, który w skrócie opowiada kobiecie o pracy u zegarmistrza, o tym, że musiał od niego odejść w wyniku nieszczęśliwego wypadku z zaginionym zegarkiem, po czym tułając się po różnych domach - trafił do zamożnego miłośnika zegarów, który posłał go do genewskiej Szkoły Zegarmistrzów. Dalsza część rozmowy dotyczy kradzieży zegarka, dokonanej - jak informuje kobieta - przez żonę pana Artena. Jan zaczyna dokładnie przywoływać i analizować wydarzenia z owego nieszczęśliwego dnia. Jednak okazuje się, że coś umknęło jego uwadze. Pani wyjaśnia mu sytuację tak, jak wyglądała ona z punktu widzenia żony zegarmistrza. Gdy Jan pracował ,przy swoim warsztaciku, nieopodal okna wystawowego, patrzyt przez lupę $i$ byt zwrócony twarza do ulicy" ${ }^{\prime 37}$, a wszelkie inne odgłosy zagłuszał turkot wozu przewożącego węgiel, do sklepu - od strony mieszkania - weszła pani Arten i zabrała zegarek. Okazuje się, że Jan - a zarazem i odbiorcy utworu - byli świadkami kradzieży.

\footnotetext{
36 J. Szaniawski: Stużbista, s. 294.

37 J. Szaniawski: Zegarek, s. 336.
} 


\section{NIEDOMÓWIENIA I NIEDOPOWIEDZENIA}

Zjawisko niedopowiedzenia występuje jedynie w dwóch omawianych dramatach w utworze Adwokat i róże oraz w Zegarku. W pierwszym z dzieł o wydarzeniach rozgrywających się w trakcie rozmowy Mecenasa i Agenta, odbiorca dowiaduje się dopiero w akcie II - zabieg ten, jest bardzo często stosowany w słuchowiskach radiowych. W akcie II na terenie posiadłości Mecenasa pojawia się pewna Dama. Czekając na Adwokata, rozmawia z Łukaszem. Dama ma zamiar prosić Mecenasa, aby podjął się obrony jej syna - Złodzieja róż. Okazuje się, że owa Dama to „piękna Frania”. W didaskaliach autor zwraca uwagę na ton głosu kobiety - pewny i energiczny - który spowodował, że Mecenas rozpoznał w Damie swoją dawną klientkę. W rozmowie z Adwokatem wspomina czas, który upłynął między jej rozprawą, a czasem teraźniejszym. Jednak w jej wypowiedzi, pojawia się wiele niedomówień, nie mówi wprost o swojej przeszłości, odbiorca musi się wielu rzeczy domyślać: „,Wkrótce po tej rozprawie wyszłam za mąz. Mąz mój już teraz nie żyje... Wywiózł mnie daleko stąd, uczyt, pokazywał po świecie rzeczy piękne... Poza tym, ot, jak w życiu, czasem, to co nazywamy „lepiej”, czasami ,gorzej”... Tak... wiele od tego czasu minęło lat... Zmieniłam się... Opanowałam swój zbyt bujny temperament, zdobyłam to, co się nazywa „wyrobieniem towarzyskim”, zmieniłam nazwisko, nawet imię, teraz mam bardziej dystyngowane. Pan jeden, co doszukat się jeszcze we mnie rysów , pięknej Frani”. Bo nikt inny o mojej przeszłości nie wie. Nie wie nawet syn:. ${ }^{38}$

Niedopowiedziane zostają także kwestie Marka i Adwokata w III akcie. Wypowiedzi wspomnianych bohaterów dotyczą obrony Złodzieja róż przeprowadzonej w Sądzie przez Marka. Mecenas stwierdza, że ta sprawa była egzaminem zarówno dla niego, jak i dla jego ucznia, ponieważ Marek bronił po raz pierwszy, Adwokat natomiast bronił Złodzieja, chcącego skraść róże z jego ogrodu, a więc człowieka, który „,wyrządził zło na jego podwórku”. ${ }^{39}$ Marek natomiast zaznacza, że dla niego sprawa była łatwiejsza, ponieważ kradzież nie dotyczyła jego własności. Odbiorca może jedynie domyśleć się, że obu bohaterom tak naprawdę nie chodzi o róże, ale o Dorotę. Niedomówienia zawarte w tymże utworze sprawiają, że dramat Szaniawskiego staje się dziełem otwartym.

Zaś niedomówienie w Zegarku pojawia się w momencie końcowej rozmowy Jana z Szefem, w której poruszane zostają przypuszczenia, kto mógł ukraść zegarek. Jan nie chcąc wyjawić Artenowi prawdy o jego żonie, snuje przypuszczenie, że kradzieży mógł dokonać diabeł. Szefowi trudno uwierzyć w takie wyjaśnienia, ponieważ nie ma pewności, że diabeł istnieje naprawdę. Według Jana mógł on

\footnotetext{
38 J. Szaniawski: Adwokat i róże, s. 225-226.

39 Tamże, s. 270.
} 
wejść ,, od ulicy, może od strony... mieszkania... ${ }^{40}$ czym sugeruje, że złodziej obrał właśnie taką drogę.

Reasumując. Akustyka i elementy dźwiękowe pojawiają się we wszystkich wspomnianych utworach. W dziele Adwokat $i$ róże służą przede wszystkim do ukazania pojawiania się poszczególnych osób oraz dookreśleniu miejsca rozgrywania się akcji. W Żeglarzu Szaniawski ukazywał przede wszystkim, nacechowaną emocjonalnie, ciszę oraz akustykę ujawnianą w wypowiedziach bohaterów. Mniejsze znaczenie zaś mają elementy dźwiękowe. Taki sam zabieg został zastosowany w Ptaku. W Stużbiście natomiast elementy dźwiękowe nie zostały wyeksponowane w takim samym stopniu jak w poprzednich dramatach. Tutaj autor więcej uwagi poświęca na zaznaczenie intonacji, tonu, pauz oraz emocji w wypowiedziach bohaterów. Zupełnym przeciwieństwem Stużbisty jest Zegarek, obfity w różnorodne elementy dźwiękowe, wskazujące na przestrzeń. Dialogi we wspomnianych dramatach najczęściej opierają się na krótkiej wymianie zdań, bądź na pytaniach i rzeczowych odpowiedziach. Inaczej jest jedynie w Zegarku, gdzie wypowiedzi bohaterów zazwyczaj są rozbudowane. Rozmowy bohaterów ukazują przede wszystkim wykonywane przez nich w danej chwili czynności, ich nastroje oraz wygląd. Dialogi (wyjątek stanowi jedynie Adwokat i róże) stylizowane są na formę języka mówionego, potocznego. Relacji mającej na celu przybliżenie odbiorcy wydarzeń, rozgrywających się poza obszarem akcji dramatu, Szaniawski nie zastosował jedynie w Zegarku. Wprowadzenie relacji daje odbiorcy możliwość stworzenia wyobrażenia o obserwacji dwóch miejsc w tym samym czasie. Zabieg ten, jak ma to miejsce w Ptaku i Stużbiście, uzasadnia także dalszy przebieg akcji. Jedynie $\mathrm{w}$ trzech $\mathrm{z}$ omawianych utworów pojawia się zjawisko retrospekcji, wpływające w znacznym stopniu na wyobraźnie odbiorców. Celem retrospekcji w słuchowiskach radiowych jest wyjaśnienie ważnych, dla dalszego przebiegu akcji, spraw z przeszłości bohaterów. Natomiast zabieg wprowadzenia niedomówień Szaniawski zastosował wyłącznie w Zegarku oraz Adwokacie i różach. Taki zabieg powoduje, że utwór uzyskuje kompozycję otwartą, wypowiedzi oraz wydarzenia mogą zostać różnie odczytywane i uzupełniane przez czytelników.

\section{BIBLIOGRAFIA:}

Hutnikiewicz A., Wstęp (w:) Szaniawski J., Wybór dramatów, Wrocław 1988.

Kolińska K. Szaniawski. Zawsze tajemniczy, Warszawa 2009.

Kwiatkowski M.J., Polskie Radio 1925-1939, „Pamiętnik Teatralny” 1973, z. 3-4.

Nastulanka K., Jerzy Szaniawski, Warszawa 1973.

Wójciszyn-Wasil A., Sztuka radiowa w Polsce i jej krytyka do 1939 roku, Lublin 2012.

${ }^{40}$ J. Szaniawski: Zegarek, s. 346. 


\section{Streszczenie:}

Jerzy Szaniawski, znany także jako „Milczek z Zegrzynka”, niewątpliwie - parafrazując wypowiedź Gombrowiczowskiego profesora Bladaczki - wielkim dramaturgiem radiowym był. Jego dramaty, takie jak chociażby Adwokat i róże, Ptak, Żeglarz, Zegarek, Stużbista, obfitują w elementy niezbędne dla sztuki radiowej. Szaniawski w swoich dziełach dążył do maksymalnej uniwersalizacji tematyki, miejsca i czasu. Ukazywał duszę swoich bohaterów, wyraźnie zarysowywał ich portrety psychologiczne. Dramaturg współpracę z radiem rozpoczął Zegarkiem w 1935 roku. Pisarz wykazywał niezwykłą wrażliwość artystyczną, dzięki której z wyczuciem wkomponowywał w swoje dzieła elementy niezbędne do powstania słuchowiska. Są to przede wszystkim elementy dźwiękowe, akustyczne, dialogi oraz relacje, występujące we wszystkich dramatach, retrospekcje, zastosowane wyłączne w trzech utworach - Adwokat i róże, Stużbista i Zegarek, oraz niedomówienia i niedopowiedzenia, które autor wplótł w dramaty Adwokat i róże oraz Zegarek. Wszystkie z wymienionych elementów budujących słuchowiska radiowe służą pobudzeniu zmysłu słuchu odbiorcy, a co za tym idzie, budowania świata przedstawionego $\mathrm{w}$ jego wyobraźni.

Słowa kluczowe: Jerzy Szaniawski, radio, dramat, słuchowisko radiowe, dźwięk, dialog

\section{RADIO DRAMATURGY BY JERZY SZANIAWSKI}

\section{Sum mary}

Jerzy Szaniawski was undoubtedly a great radio playwright. His dramas, such as Adwokat i róże / The Attorney and Roses/, Ptak /The Bird/, Żeglarz/The Sailor/, Zegarek/The Watch/, Stużbista/The Official, teem with elements that are essential for a radio play. In his works, Szaniawski aimed at full generalisation of the theme, place and time. He pictured the souls of his characters and clearly portrayed their psychological delineation. Szaniawski started his cooperation with radio in 1935 with his play The Watch. Due to his exceptional artistic sensibility he was able to integrate into his works the elements which are crucial for a radio play. These are, primarily, audio elements, dialogues and narratives that are present in all his dramas, retrospections, which appear only in three plays: The Attorney and Roses, The Official and The Watch, as well as reticence and understatements employed in Attorney and Roses and The Watch. All of the above mentioned elements aim at stimulating the listeners' sense of hearing and consequently creating the represented world in their imagination.

Keywords: Jerzy Szaniawski, radio, drama, radio play, sound, dialogue 